\title{
FINANCIAL ANALYSIS OF GREEN PETROLEUM COKE AS A COAL BLEND IN STEEL INDUSTRY TO SUPPORT NATIONAL ENERGY SECURITY
}

\author{
Khoirun Naimah ${ }^{1^{*}}$ \\ Nugroho Adi Sasongko ${ }^{2,3}$ (i) \\ Rudy Laksmono Widayatno ${ }^{2}$
}

\begin{abstract}
${ }^{1}$ Department of Energy System Engineering, Institute Technology of Sumatera, Indonesia
${ }^{2}$ Department of Energy Security, Indonesia Defense University, Indonesia

${ }^{3}$ Agency for The Assessment and Application of Technology (BPPT), Indonesia
\end{abstract}

\section{ABSTRACT}

Green Petroleum Coke (GPC), produced by Pertamina RU II Dumai, is the product of refined petroleum, which still has good quality but has not been utilized to its full potential. Such as Sulfur 0.5\%; FC 86.03\%; Ash 0.10\%; VM 13.82\%; Moist 10, 52\%; and the calorific value of $7500 \mathrm{kcal} / \mathrm{kg}$. Therefore, one effort that can do is diversification, namely the use of GPC as a mixture of other fuels (fossil) to increase the selling value of GPC. This diversification is also in line with the national energy policy in PP. 79/2014 that the program aims to increase the availability of national energy sources. This study aims to determine the feasibility of using GPC as a coal mixture in Industry (Krakatau Steel) with an overview of economic aspects. Data obtained by qualitative methods consisting of interviews, observation, and documentation. Based on the research results from 2 scenarios, both scenario 1 (GPC $4 \%$ ) and scenario 2 (GPC 18\%), it is found that the NPV is positive, IRR is above the discount rate, and $B C R>1$. Thus, the use of GPC as a coal mixture is considered feasible to run and can support national energy security.

Keywords: Diversification, Feasibility, Petroleum Coke, Investment Decision

\section{ARTICLE INFO}

Received: January $19^{\text {th }}, 2021$

Revised: October $28^{\text {th }}, 2021$

Accepted: November $5^{\text {th }}, 2021$

Online: November $25^{\text {th }}, 2021$

*Correspondence:

Khoirun Naimah

E-mail:

khoirun.naimah@tse.itera.ac.id

JEL: G11, G32

To cite this document: Naimah, K., Sasongko, N. A., Widayatno, R. L., (2021). Financial Analysis of Green Petroleum Coke as A Coal Blend in Steel Industry to Support National Energy Security. JDE (Journal of Developing Economies), 6(2), 275-285

\section{Introduction}

Government Regulation from PP No. 79/2014 article 3 paragraph 2 has stated two central policies in KEN (national energy policy). Namely, the availability of energy for national needs and the utilization of national energy resources is supported by the supporting policy in paragraph 3 , namely energy diversification.

Article 1 explains that energy diversification is the diversification of energy sources (something that can produce energy directly or through conversion or transformation). The purpose of energy diversification is none other than to not depend on only one type of energy. In the current condition, Indonesia still has a high dependence on fossil fuels. It can be seen from a kind of fossil fuel that is still widely used, namely coal. Coal is still the cheapest 
fossil energy fuel and the most commonly used by various industries. In Indonesia's 2015 energy mix, coal has a $33.8 \%$ share. The use of coal will be $30 \%$ in 2025 . Meanwhile, petroleum in 2025 is still $25 \%$. It means that fossil energy until 2025 is still the primary choice, and Indonesia's energy security is still in an adequate/mediocre condition. Thus, it is necessary to diversify energy other than coal which is more environmentally friendly and better quality. In particular, the iron and steel industry uses coal as the primary fuel, which uses high heat to produce molten iron. Several industries that use coal include the power generation industry, cement, iron and steel industries, etc.

The iron-steel industry, such as the state-owned company PT Krakatau Steel has been known since 2017 to diversify its ironmaking energy sources. Namely, the establishment of coal-based Blast Furnaces (BF) to reduce dependence on natural gas, production costs and increase production steel production capacity. The coal is processed into coke, which is then used as a conversion material for BF, which functions as a buffer for iron material, an iron-reducing agent, and a fuel. However, the coal used is $60 \%$ imported.

One type of fuel that is considered to have the potential to substitute coal as a form of diversification of energy sources is GPC (Green Petroleum Coke). GPC is a by-product of petroleum processing in the form of carbon which is solid and black. Indonesia produces GPC at Pertamina RU II Dumai in a Delayed Cooking Unit (DCU) with a capacity of 360 thousand tons/ year. This coke is called Green Coke because it has a lower ash content, namely $0.10 \%, 13.82 \%$ volatile matter, low sulfur, $0.50 \%$, a reasonably high carbon value of $85-86 \%$, and a calorific value. Which is higher, namely 7,500-8,500 kcal/ $/ \mathrm{kg}$, than coal with $5,000-6,000 \mathrm{kcal} / \mathrm{kg}$ heat type. Currently, the selling value of GPC is still lower (around 2-3\%) compared to other petroleum products (Edwards, 2015). Therefore, data from PT Pertamina (2018), GPC products are exported abroad, such as to China and India. Thus, it has not been utilized for domestic interests to the fullest. So, in assessing these opportunities, it is necessary to analyze economic feasibility so that GPC can be maximally utilized in the country, support the diversification of energy sources, and increase the selling value of GPC.

\section{Literature Review}

In Canada, petcoke production has been carried out for 10 million tons/year. Even in the United States, it also produces 61.5 million tons/year. The higher calorific value of petcoke than coal and lower $\mathrm{CO} 2$ emissions. Economically, the use of petcoke with a portion of $20-30 \%$ as a coal mixture can be 2 million USD/year (Stockman et al., 2013). Then, petcoke is also very stable and non-reactive in environmental conditions, and petcoke is released from the category of hazardous solid waste according to RCRA and is not considered a hazardous substance according to CERCLA (Andrews \& Lattanzio, 2014). However, from the study results of the effects of using petcoke on health, it was found that the main threat posed was to the population around the petcoke pile, namely the emission of fugitive dust in the form of fine particles (Caruso et al., 2015). It is also felt by Pertamina RU II Dumai in storing and producing petcoke. Recent trends in India indicate that the consumption of petcoke in India has been increasing partly due to the increase in petcoke consumption by the cement industry. Some of the actions taken by the Indian side in environmental management. Including calculating petcoke emissions, integrating petcoke in the US-Asia strategic and commercial dialogue, creating a South Asia Energy Data Center, and developing public-private partnerships to accelerate petcoke innovation (Gordon \& Livingston, 2017).

The petroleum coke (petcoke) research for the Metallurgical Industry in Nigeria shows that they are burdened with material capital purchases of raw imported petcoke for iron pro- 
duction. Meanwhile, he has a petroleum refinery but no petcoke output yet. The price difference between heavy crude oil and crude oil is 4-10 USD/barrel. So Nigeria must simultaneously develop the two industries to benefit both profit and qualitatively (Nigeria content and participation). From Nigeria's experience, Indonesia should have taken advantage of domestic GPC and not just exports (Akpabio \& Obot, 2011). Technically, research that has conducted trials lab scale that the use of $5 \%$ \& $10 \%$ petcoke with low VM $(<12 \%)$ was able to reduce coke ash but caused a decrease in the level of fluidity (Kiran et al., 2013).Then, Petcoke with sulfur $<1 \%$ can be used directly to substitute for coal in the furnace. The HGI content of petcoke is greater than the Calcined petcoke, so it is more suitable for use as a fuel because less energy is used in grinding (Santos et al., 2015). The research by Jackman et al. (1960) on the pilot scale and Price et al. (1980) on the pilot scale and Price et al. (1980) on the lab scale to substituting low volatile coal with petcoke shows that the percentage produced is at $15-20 \%$. In this percentage, it can obtain that the quality of coke for BF needs is better, such as increasing the strength/hardness of coke and stabilizing coke. Still, economic analysis has never been carried out.

Green Petroleum Coke (GPC) is a residue or by-product from processing petroleum in the form of solids that have undergone an increase in quality, characterized by low levels of ash and sulfur and high carbon and calorific values. The following is a green coke product specification from PT. Pertamina (Persero) RU II Dumai has a low sulfur content of max $2 \%$, contains $80 \%$ fixed carbon content, and a calorific value of $7500 \mathrm{Kcal} / \mathrm{Kg}$, so that it can still be used as fuel. Therefore, this coke is called green coke. Figure 1. shows the physical form of green coke Pertamina RU II Dumai products, which are granular and black. Physically, GPC has the same characteristics as coal, which is black and granular in shape. It can be seen in Figure 1.

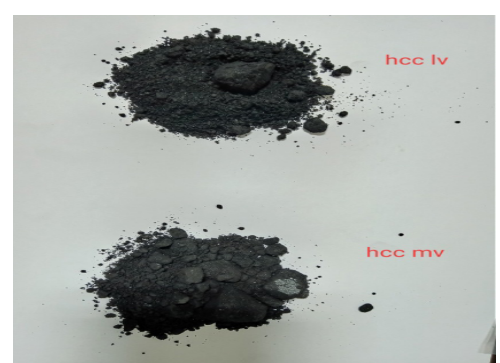

(a)

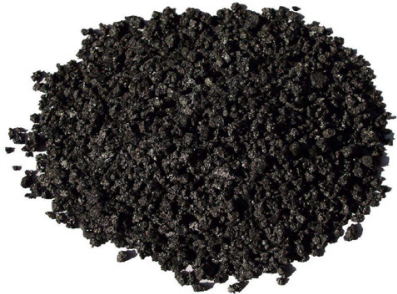

(b)

Figure 1: Comparison of GPC with coal (a) GPC and (b) HCC coal.

Source: Technocal Specification Green Coke RU II Dumai and HCC coal from Krakatau Steel

A comparison of HCC and petcoke coal quality based on Posco standards can be seen in Table 1. From Table 1. It can see that petcoke is included in the SSCC category. It has the opportunity to increase the supply of raw materials for Krakatau Steel from domestic (diversification) and reduce import volume.

Table 1: Coking coal Classification (Posco standar)

\begin{tabular}{|c|c|c|c|c|c|c|c|c|}
\hline \multirow{2}{*}{ Parameter } & \multicolumn{3}{|c|}{ Hard Coking coal (HCC) } & \multirow{2}{*}{$\begin{array}{c}\text { Semi } \\
\text { Hard Cok- } \\
\text { ing coal } \\
\text { (SHCC) }\end{array}$} & \multicolumn{2}{|c|}{$\begin{array}{l}\text { Semi Soft Cok- } \\
\text { ing coal (SSCC) }\end{array}$} & \multicolumn{2}{|c|}{ Antrasit } \\
\hline & $\begin{array}{l}\text { High Flu- } \\
\text { idity }\end{array}$ & $\begin{array}{l}\text { Medium } \\
\text { Fluidity }\end{array}$ & $\begin{array}{l}\text { Low } \\
\text { Fluidity }\end{array}$ & & $\begin{array}{l}\text { Semi } \\
\text { Soft }\end{array}$ & $\begin{array}{l}\text { Pet } \\
\text { Coke }\end{array}$ & Antrasit & $\begin{array}{l}\text { Semi Antr- } \\
\text { asit }\end{array}$ \\
\hline $\begin{array}{l}\text { Long Max Fluid- } \\
\text { ity (LMF) }\end{array}$ & $\leq 4,0$ & $\leq 3,0$ & $\leq 2,0$ & $\geq 3,3$ & - & - & - & - \\
\hline
\end{tabular}




\begin{tabular}{|c|c|c|c|c|c|c|c|c|}
\hline \multirow{2}{*}{ Parameter } & \multicolumn{3}{|c|}{ Hard Coking coal (HCC) } & \multirow{2}{*}{$\begin{array}{c}\text { Semi } \\
\text { Hard Cok- } \\
\text { ing coal } \\
\text { (SHCC) }\end{array}$} & \multicolumn{2}{|c|}{$\begin{array}{l}\text { Semi Soft Cok- } \\
\text { ing coal (SSCC) }\end{array}$} & \multicolumn{2}{|c|}{ Antrasit } \\
\hline & $\begin{array}{l}\text { High Flu- } \\
\text { idity }\end{array}$ & $\begin{array}{l}\text { Medium } \\
\text { Fluidity }\end{array}$ & $\begin{array}{l}\text { Low } \\
\text { Fluidity }\end{array}$ & & $\begin{array}{l}\text { Semi } \\
\text { Soft }\end{array}$ & $\begin{array}{l}\text { Pet } \\
\text { Coke }\end{array}$ & Antrasit & $\begin{array}{l}\text { Semi Antr- } \\
\text { asit }\end{array}$ \\
\hline Ash (\%) & $\geq 7,5$ & $\geq 8,5$ & $\geq 9,5$ & $\geq 10,5$ & $\geq 9,5$ & $\geq 1,0$ & - & - \\
\hline VM (\%) & $23-34$ & $23-28$ & $12-23$ & $17-34$ & $28-34$ & $14 \geq$ & $10-16$ & $<6$ \\
\hline $\mathrm{S}(\%)$ & $\leq 0,9$ & $\leq 0,7$ & $\leq 0,75$ & $\leq 0,8$ & $\leq 0,6$ & $\leq 2,5$ & - & - \\
\hline
\end{tabular}

Source: Overview COP Krakatau Steel, 2019

Krakatau Steel has established the BF Complex as an area that utilizes coking coal to diversify energy sources to reduce dependency and face rising natural gas prices and the burden of existing production costs. Most of the raw material supply conditions in the BF Complex are imports. Iron ore is $100 \%$ imported from Brazil and Australia, and $60 \%$ of coal is imported from Australia, and $40 \%$ is obtained from domestic sources, namely Central Kalimantan. More details can be seen in Figure 4.5 for coal supply flows. This coal import was carried out because Indonesia did not have coal with the character of the HCC (Hard Coking coal) type as in Table 2. and did not yet have the commercial technology to produce coke suitable for use in the iron-steel industry.

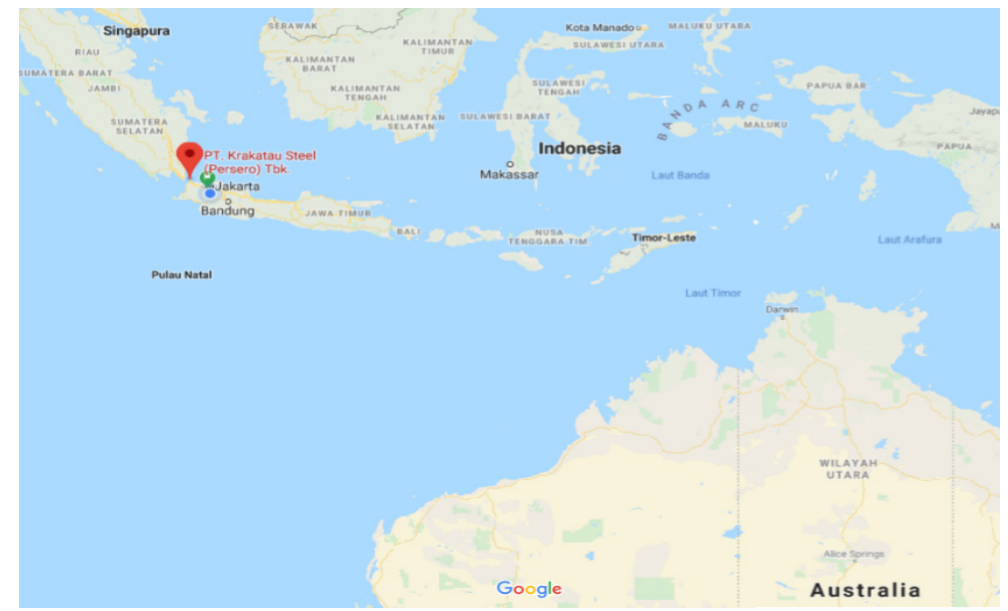

Figure 2: Coal supply flow used by Krakatau Steel

When the supply is experiencing problems, the industry cannot operate when it only depends on one energy source. Diversification of energy sources with other types of energy, especially those with the same characteristics as coal, is needed.

Financial analysis is carried out to see the economic feasibility of the investment decision of using GPC as a coal mixture. It is done to make an efficient allocation of energy resources. Through a financial feasibility analysis, it can see that the estimated cost or/and cash flow will later determine whether a project or activity is feasible or not. In other words, this is to determine whether the activity will be profitable during the life of the activity (Husnan \& Suwarsono, 2000). In doing calculations, an important thing to consider is the time value of money based on the measure, namely the time of cash flows that occur after the project starts (Aryansyah \& Indryani, 2012). The project feasibility analysis is carried out based on the feasibility category such as Net Present Value, Payback Period, Benefit Cost Ratio, and Sensitivity analysi The project feasibility analysis is carried out based on the feasibility category such as Net Present Value, Payback Period, Benefit-Cost Ratio, and Sensitivity analysis (Sanusi, 2000; Supriyadi, 2019). 


\section{Data and Reseacrh Methods}

In this research, we used qualitative studies at the Krakatau Steel industry Tbk through interviews, observation, and documentation. As much data is collected in the field, the data is analyzed and can conclude. Qualitative research is used to explore and understand the meaning of such events, circumstances, or phenomenon (Creswell, 2013). GPC has not been used domestically and has only been exported. So, the researcher wants to analyze what-if GPC is used as a coal mixture in Krakatau Steel, which is part of the coal import minimization program and diversification of raw materials through financial feasibility analysis. It researched Pertamina RU II Dumai to obtain GPC data (production data, composition, and prices). The Krakatau Steel industry to study the financial feasibility of using GPC from RU II Dumai as a coal mixture in the Blast Furnace (BF) (investment, production, maintenance, and so on). The data obtained were analyzed for financial feasibility such as Present Net Value (NPV), Payback Period (PP), Internal Rate of Return (IRR), and Benefit-Cost Ratio (BCR) (Sanusi, 2000; Supriyadi, 2019). So, from the results of this analysis, we can obtain policies or next steps to follow up on the project using GPC as a coal blend.

\section{Findings and Discussions}

GPC is produced by PT Pertamina (Persero) RU II Dumai at the Coke Chamber Delayed Cooking Unit (DCU) with 360 thousand tons/year capacity. GPC has various benefits, including being used directly as a fuel (mixed with coal) in industrial power plants and boilers in the factory cement plant. Used directly by utilizing the carbon content in the GPC well as fuel that has low sulfur and carbon high in the iron-steel industry, and can be used as a raw material for making calcined coke used as a decomposition process between alumina slurry and other materials in the aluminium industry.

So, with these various benefits, GPC can be used as a form of diversification of energy sources that are more environmentally friendly so that Indonesia does not only depend on one type of energy source, which will undoubtedly reduce coal imports. So it can also reduce state spending to buy coal imports. GPC, which RU II Dumai in Indonesia produces, is processed by thermal cracking at a temperature of $500^{\circ} \mathrm{C}$ for 24 hours by utilizing short residue, the bottom HVU product. The results of the GPC analysis consisted of the water content of $10.52 \%$, sulfur $0.5 \%$, VM $13.82 \%$ and ash $0.10 \%$. However, several parameters were not analyzed by RU II Dumai, such as CRI, CSR, M10, and M40. Thus, the data is obtained through a secondary data approach. From secondary data, petcoke has a CSR of $40-63 \%$ and a CRI of 19 $20 \%$ (Rodero, 2015). Based on Table 1, it can see that petcoke is included in the SSCC category, so it can increase the supply of raw materials for Krakatau Steel from domestic (diversification) and reduce the volume of imports.

A financial feasibility analysis is conducted to determine the feasibility of using GPC as a coal mixture from an economic point of view. The financial feasibility analysis is carried out on projects from upstream to downstream, starting from the procurement of raw materials to coke products, both used for BF and sale. The financial analysis was carried out on the discount rate standard Bank Indonesia, which is $12.5 \%$ per annum or $1.04 \%$ per month.

The analysis was carried out with two scenarios, namely $4 \%$ and $18 \%$, assuming five years. The use or blending mechanism of $4 \%$ and $18 \%$ GPC results from calculations carried out with the steel industry operator. The main aspect is adjusted to the aspect of the Volatile Matter content. The standard is $24-25.5 \%$, with a composition of $60 \%$ HCC, $20 \%$ SHCC, and $20 \%$ SSCC, the VM is $25.35 \%$. When GPC is added by reducing the HCC portion, the VM cannot be $<24 \%$ and $>25.5 \%$. If $<24 \%$, it will interfere with the push process in the Coke Oven Battery 
and if $>25.5 \%$, the yield of coke products will decrease. From these data, the GPC is blending that meets VM $24-25.5 \%$ is $4-18 \%$ with VM $25.06 \%-24.08 \%$. The use of GPC does not require modification of the Blast Furnace because the specifications of the Volatile Matter (VM) content of the input raw materials have been adjusted. Other assumptions used are a $1 \%$ increase in GPC prices per year, increase in services, fixed costs, and O\&M of 5\% per year, increase in electricity by $5 \%$ per 3 years, and $2.5 \%$ income tax. The feasibility value parameter is reviewed from the NPV (Net Present Value), IRR (Internal Rate of Return), BCR (Benefit Cost Ratio), PP (Payback Period) and Sensitivity Analysis to ensure business certainty under changes in normal conditions. NPV, IRR, BCR, and PP can be calculated by doing the preparation element calculation of the investment value, total cost, and revenue values.

The investment value is the capital or cost component required to substitute coal with GPC in the coke production to generate profits. The cost components included in the calculation are an investment, production costs, and income. The investment consists of technical study costs, which are assumed to be one team consisting of 5 people, GPC Weighing Conveyor System, GPC Reclaimer System, and GPC Stoccile with an additional 4\% GPC of 773,214 USD and $18 \%$ GPC of 921,429 USD. Production costs consist of raw material costs (Calculation of GPC/tonne price, shipping costs, and several tons of GPC), electricity utilities (with the addition of GPC will add 1 unit mixing bin, so a total of 5 bins. At $4 \%$, electricity usage will increase by $90,650 \mathrm{kwh}$ or IDR 6,364 / month and if $18 \%$ increases by $407,925 \mathrm{kwh}$ or IDR 28,555 / month), outsourcing services, maintenance, and fixed costs. The total cost of production with $4 \%$ GPC is 435,405 USD/month and for $18 \%$ GPC it is $1,796,841$ USD/month. The revenue value is derived from the sale of COP products such as coke, by-products such as tar, benzol, ammonium sulfate, sulfur, and BF products such as hot-metal and slag. Total revenue with $4 \%$ GPC is 578,014 USD/month and $18 \%$ GPC is $2,600,237$ USD/month. After calculating, the results show that the NPV, PP, IRR, and BCR for both scenarios show that the assessment is feasible to run. It can be seen in Table 2 below.

Table 2: Result of analysis of financial from GPC mixture

\begin{tabular}{ccccc}
\hline GPC (\%) & NPV & PP & IRR & BCR \\
\hline 4 & 4.857 .359 & $7^{\text {th }}$ month of the first year & 12,82 & 1,27 \\
\hline 18 & 25.174 .291 & $2^{\text {nd }}$ month of the first year & 33,75 & 1,32 \\
\hline
\end{tabular}

Source: Processed by the author

The financial feasibility analysis results in Table 4 shows that the project with the $4 \%$ and $8 \%$ GPC scenario obtained a positive NPV value if NPV >0 (positive NPV) shows that the benefit is greater than the cost of making the project feasible (Sanusi, 2000; Supriyadi, 2019). The difference between the two scenarios is only in the magnitude of the values. In the $4 \%$ scenario, the payback period is in the 8 th month of the first year. While in the $18 \%$ scenario, the payback period is in the 2 nd month of year 1 . The $18 \%$ scenario has a payback period that is faster than $4 \%$. It shows that with the existing plant design at Krakatau Steel, coal substitution with GPC can be run with a per cent usage of $18 \%$ and will return on investment in the 2 nd month of the first year. The IRR results also show that in the $4 \%$ scenario. The IRR is $12.82 \%$ per month, and in the $18 \%$ scenario, the IRR is $33.75 \%$. The IRR results are above BI standards. It means that the project can continue or be safe for the possibility of an increase in the discount rate caused by the rise in inflation. The project will still have a positive NPV up to the limit of the IRR value. The BCR results of both scenarios show a value of more than 1 , meaning that the benefits or benefits during the project's technical-economic life are more significant than the costs incurred, so this project is feasible to run. 
The next component of financial analysis is sensitivity analysis. This analysis was carried out after obtaining the NPV, PP, IRR, and BCR results in normal conditions (100\%). Sensitivity analysis is an analysis used to see the effect on the project due to the possibility of changing circumstances or conditions to ensure business certainty. In this GPC substitution, there are several elements in costs, income, and investment that experience changes/uncertainties that impact changes in the value of costs and benefits in the future. By calculating this value, business actors will have an overview and strategy in dealing with change. The elements assumed to affect the value of NPV, PP, IRR, and BCR in this study are an investment, GPC costs, and raw material income (lowering the cost of importing HCC coal).

These elements are taken because these three elements provide the most significant portion compared to others. So, if the part changes just a little, it will affect the NPV, IRR, PP, and BCR. Change assumptions are taken at a decrease of 90 and $80 \%$ and 110 and $120 \%$. It means that the three parameters will experience a reduction or increase of $10 \%$ and $20 \%$. This assumption is made because it takes a low standard to predict a significant reduction. If a low reduction has a high sensitivity, then the standard can be used as an illustration for preventing an even more substantial decline. The sensitivity analysis results can be seen in Figures 3, 4, 5 , and 6 .

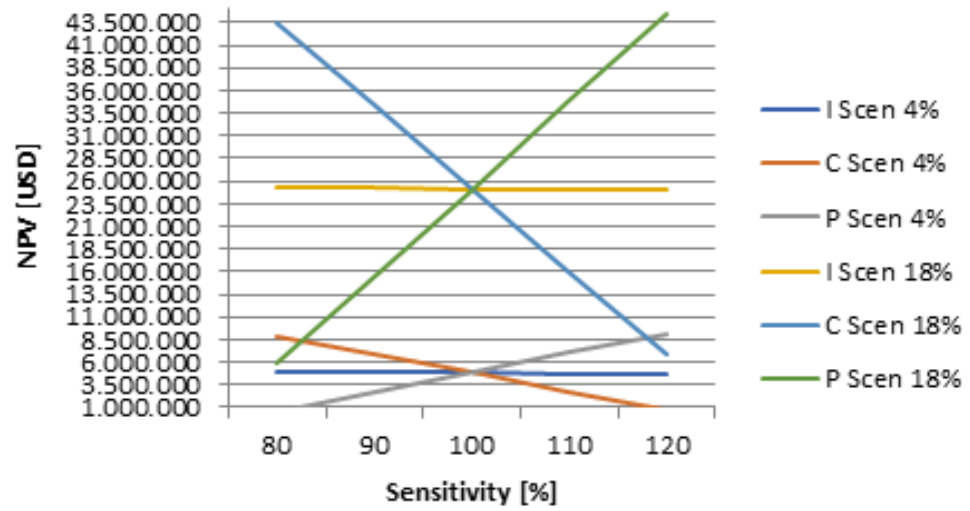

Figure 3: Graph of sensitivity I, C, R to NPV in scenario $4 \%$ and $18 \%$ Source: Processed by the author

From Figure 3, it can see that income is the one with the highest sensitivity in the $4 \%$ and $18 \%$ scenarios. It means that coal imports have a very significant impact on the NPV value. If coal prices fall, income will also decrease so that the NPV value also decreases. For example, for the 4\% GPC scenario, if the income sensitivity is $90 \%$ and $80 \%$, the NPV will decrease, while at $110 \%$ and $120 \%$, the NPV will increase. It is inversely proportional to cost sensitivity. If the cost sensitivity is $110 \%$ and $120 \%$, then the NPV will decrease, and when the cost sensitivity is $90 \%$ and $80 \%$, the NPV will increase. It is also applied to the parameters of cost. The higher the price of GPC in the system blending, the cost of production will go up. The condition taken in this study is the price in August 2019, where GPC is lower than coal. Thus, reducing coal imports will provide additional income, which will increase the NPV value. This condition is expected from this project so that it can achieve its primary objective. It does not significantly impact changes in investment because the amount is less/less than the cost and income.

However, when viewed, the higher the investment, the lower the NPV value. From Figure 1, it can also see clearly that the NPV in the scenario $18 \%$ is greater than the $4 \%$ scenario, and both scenarios are at a positive number, which means that it is still feasible to run even though the $4 \%$ scenario has a profit of not $18 \%$. In the $4 \%$ scenario, the use of GPC is less than $18 \%$. Thus, the reduction in coal imports was less than $18 \%$. Apart from being seen from 
the NPV value, it is also necessary to look at other parameters such as PP, IRR, and BCR. It is because it is not sufficient to limit the NPV of a project to be feasible. To be more convincing, Figure 4 below shows the sensitivity of investment, cost, and revenue to the PP.

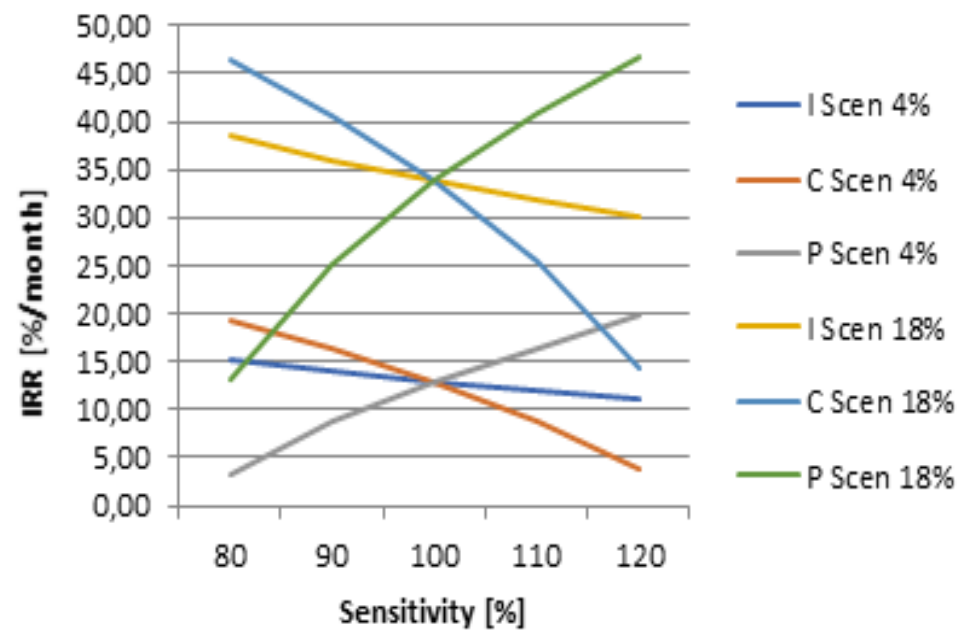

Figure 4: Graph of sensitivity I, C, R to PP in scenario $4 \%$ and $18 \%$

Source: Processed by the author

From Figure 4, it can be seen that in the $4 \%$ scenario, the parameter that has the highest sensitivity value is income. It means that the decline or increase in coal prices has a very significant impact on revenue, implications for the project's payback period. From Figure 4. the lower the HCC price, the longer the payback period will be, so that it has an impact on the lower NPV of income. It implies that the payback period is getting longer, as shown in Table 4 , which shows that the NPV of Income on the decline of $20 \%$ is the lowest at 610,539 USD. In contrast, the others are millions of USD. It also applies to cost. Cost is the second parameter that has a significant impact other than income. The higher the HCC price, the lower the NPV cost (792,640 USD), the longer the payback period. According to economic principles, the higher the costs incurred in a business, the lower the income earned so that the payback period will also be long.

In the $18 \%$ GPC scenario, as shown in Figure 4, income is also the parameter that has the highest sensitivity value. It is the same as the $4 \%$ scenario where when the coal import price is higher than the GPC price, at a $20 \%$ decrease, the payback period will be more extended because the impact on total revenue is only a little, and vice versa. Figure 4. explains that with a $20 \%$ decline in coal import prices, in the $4 \%$ scenario, the payback period is in the 29 th month, while the $18 \%$ scenario is in the 7 th month. The difference is very far, that is 22 months. The same is the case with changes in cost. With a $120 \%$ increase in coal import prices, the payback period for the $4 \%$ scenario is in the 25 th month, while the $18 \%$ scenario is in the 6th month, 11 months difference.

The sensitivity analysis carried out on both NPV and PP shows that if the import price of coal is lower than GPC. It will provide benefits and vice versa. The higher the use of GPC or the higher the decline in coal imports with these prices conditions, the coal substitution project with GPC in the $18 \%$ scenario is more profitable than the $4 \%$ scenario, although both are equally feasible. IRR obtained in Figure 5 also shows that the IRR of the $18 \%$ scenario is greater than the $4 \%$ scenario, and both are above the standard. It means that when there is a drastic decrease or increase, this project can still profit, so it is safe. From the results of sensitivity to IRR, it is found that income is also the most significant parameter compared to the others, 
either in the $4 \%$ or $18 \%$ scenario. It can be seen in Figure 5.

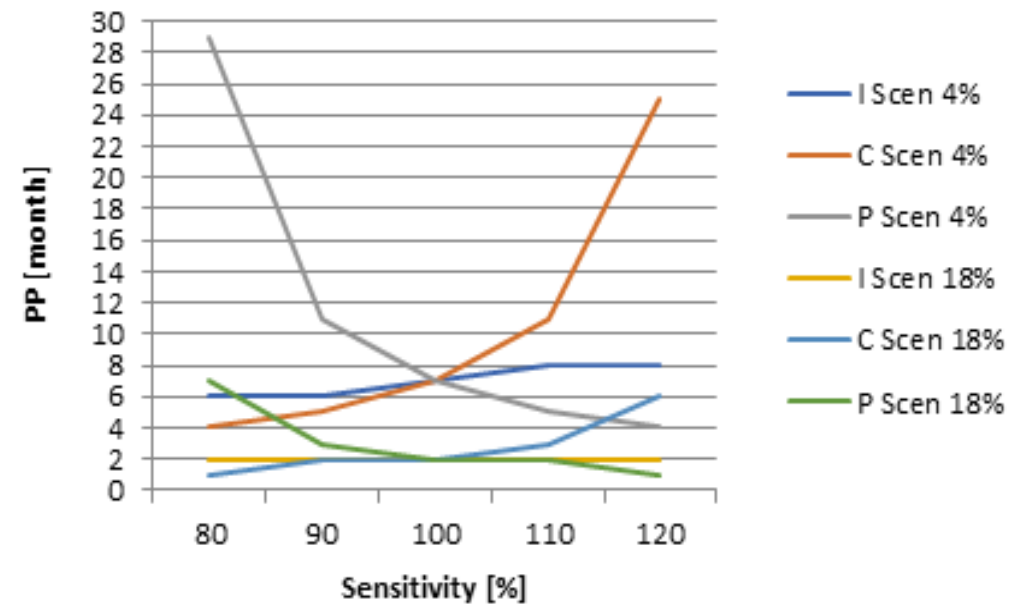

Figure 5: Graph sensitivity I, C, R to IRR in scenario $4 \%$ and $18 \%$

Source: Processed by the author

The BCR analysis results in figure 6 show that if any decrease or increase of $10 \%$ and $20 \%$, the value of $B C R$ remains above 1 . The project is still feasible to run because, at a very low or very high decrease, the benefits or benefits obtained are more significant than the costs issue. It is obtained in the following Figure 6. From Figure 6, it is found that cost is the most sensitive parameter compared to benefits. It means that when the cost changes slightly, it will significantly impact the BCR results. With a $20 \%$ increase in cost (sensitivity $120 \%$ ), the $B C R$ value obtained is accurate, namely 1.05 in the $4 \%$ scenario and 1.09 in the $18 \%$ scenario. It means that under these conditions, with fixed benefits and costs that have increased drastically, the project can still run even though the benefits obtained are only slightly more significant than the expenditure, likewise, at a reduction in the cost of $20 \%$ (sensitivity $80 \%$ ). The highest BCR value was 1.61 in the $4 \%$ scenario and 1.68 in the $18 \%$ scenario. The data shows that a reduction in the cost of $20 \%$ and fixed income will increase the value of BCR to obtain more significant benefits.

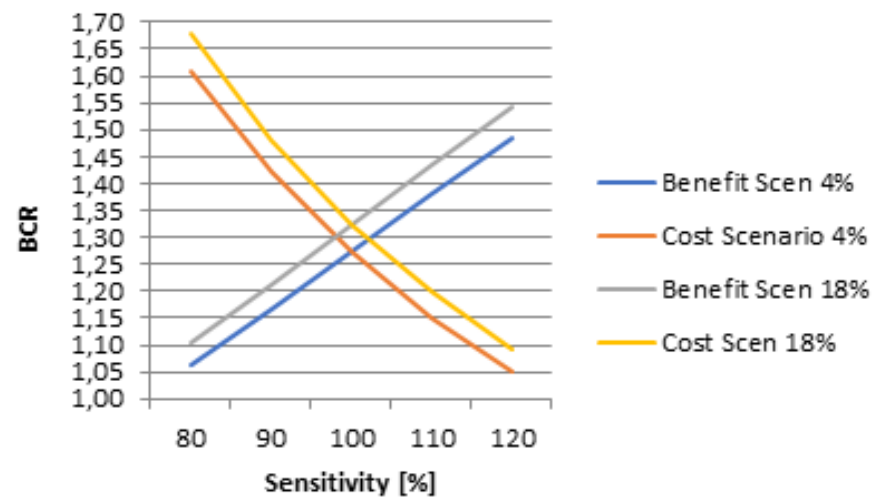

Figure 6: Graph sensitivity of B, C to BCR in scenario $4 \%$ and $18 \%$

Source: Processed by author

From an economic point of view, using petcoke as an alternative to an existing oil-fired boiler, it is found that the economic value generated from burning petcoke has changed the previously high-cost unit to a unit that is cheaper/similar to coal (Brogman, 2005). Research that reviewed the production and use of petcoke containing tar sand found that the presence 
of a mixture of petcoke in coal (10:80 or 30:70) in the power plant was able to save 120 million USD/year (Stockman et al., 2013). However, economic analysis has not been carried out through a cost-benefit analysis obtained by value/value. So from the research conducted by researchers, it is proven that using petcoke as a coal mixture has a more excellent benefit value than the costs incurred. So it is feasible to run with a note that there must be a price agreed between Krakatau Steel and Pertamina at a GPC price of 173 USD/ton.

\section{Conclusion}

GPC as a coal mixture is used as raw material for the Blast Furnace at PT. Krakatau Steel (persero) Tbk is financially declared feasible to run. It can be seen from the positive NPV parameters, logical PP, IRR above the predetermined discount rate, and $B C R>1$. So, with these results, it is hoped that GPC can be used in PT. Krakatau Steel, which can add to the selling value of GPC and support the energy source diversification program in PP No.79 of 2014 concerning National Energy Policy.

\section{Acknowledgements}

This research supported Pertamina (Persero) RU II Dumai and Krakatau Steel (persero), tbk industry.

\section{References}

Akpabio, E. J., \& Obot, O. W. (2011). Optimizing Utilization of Petroleum Coke in Nigerian Metallurgical Industry. Journal of Minerals and Materials Characterization and Engineering, 10(03), 267-278. https://doi.org/10.4236/jmmce.2011.103018

Andrews, A., \& Lattanzio, R. K. (2014). Petroleum coke: Industry and environmental issues. In U.S. Petroleum Refining: Petcoke Issues, Small Refinery Opportunities and Industry Background.

Aryansyah, N. D., \& Indryani, R. (2012). Analisa Manfaat Dan Biaya Rusunawa Jemundo, Sidoarjo. Jurnal Teknik POMITS, 1(1), 1-5. http://digilib.its.ac.id/public/ITS-paper-23168-paperpdf.pdf

Aryansyah, N. D., \& Indryani, R. (2012). Analysis of the Benefits and Costs of Rusunawa Jemundo, Sidoarjo. Jurnal Teknik POMITS, 1(1), 1-5. http://digilib.its.ac.id/public/ITS-paper-23168-paperpdf.pdf

Caruso, J. A., Zhang, K., Schroeck, N. J., McCoy, B., \& McElmurry, S. P. (2015). Petroleum coke in the urban environment: A review of potential health effects. In International Journal of Environmental Research and Public Health (Vol. 12, Issue 6, pp. 6218-6231). https:// doi.org/10.3390/ijerph120606218

Creswell, J. W. (2013). Research Design: Qualitative, Quantitative, and Mixed Methods Approaches. 4th Edition. Los Angeles, London, New Delhi, Singapore, Washington DC. In SAGE Publications.

Edwards, L. (2015). The History and Future Challenges of Calcined Petroleum Coke Production and Use in Aluminum Smelting. In JOM (Vol. 67, Issue 2). https://doi.org/10.1007/ s11837-014-1248-9

Gordon, D., \& Livingston, D. (2017). Petroleum Coke Use in India and South Asia: Recent Trends and Emerging Policy Options. Carnegie Endowment for International Peace. https://carnegieendowment.org/2017/10/01/petroleum-coke-use-in-india-and-south- 
asia-recent-trends-and-emerging-policy-options-pub-74668

Husnan, S., \& Suwarsono. (2000). Studi Kelayakan Proyek. UPP AMP YPKN.

Husnan, S., \& Suwarsono. (2000). Project Feasibility Study. UPP AMP YPKN.

Jackman, H. W., Eissler, R. L., \& Helfinstine, R. J. (1960). Petroleum Coke in Ilinois Coal Blends for Blast Furnace Coke. The Canadian Journal of Chemical Engineering, 58(3), 339-347. https://www.ideals.illinois.edu/handle/2142/42992

Kiran, K. S. P., Sivalingaraju, B., Reddy, S., Venkateswarlu, Y., Marutiram, K., \& Naha, T. K. (2013). Use of Petroleum Coke as an Additive in Metallurgical Coke Making. Proceeding of the International Conference on Science and Technology of Ironmaking and Steelmaking, 1-11.

National Energy Policy Government Regulation No. 79 / 2014

PP No.79. (2014). National Energy Policy. https://jdih.esdm.go.id/storage/document/PP No. 79 Thn 2014 (Terjemahan).pdf

Price, J. T., Gransden, J. F., \& Leeder, W. R. (1980). Pitch and petroleum coke additions to coke oven charges. The Canadian Journal of Chemical Engineering, 58(3). https://doi. org/10.1002/cjce.5450580310

PT Pertamina. (2018). Strengthening Commitment Securing Energy. https://www.pertamina. com/Media/File/ANNUAL-REPORT-PERTAMINA-2018_.pdf

Santos, A. R., da Silva, R. J., \& Grillo Renó, M. L. (2015). Analysis of Petroleum Coke Consumption in Some Industrial Sectors. Journal of Petroleum Science Research, 4(1), 01-07. https://doi.org/10.12783/jpsr.2015.0401.01

Sanusi, B. (2000). Pengantar Evaluasi Proyek. Fakultas Ekonomi UI.

Sanusi, B. (2000). Introduction to Project Evaluation. Fakultas Ekonomi UI.

Stockman, L., Turnbull, D., \& Kretzmann, S. (2013). Petroleum Coke: The Coal Hiding in the Tar Sand. Oil Change International. https://www.ourenergypolicy.org/wp-content/uploads/2013/06/OCI.Petcoke.FINALSCREEN.pdf

Supriyadi, I. (2019). Manajemen Energi: Cost Benefit Analysis Book Module. Unhan.

Supriyadi, I. (2019). Energy Management: Cost Benefit Analysis Book Module. Unhan. 